\title{
Variations in level of oil, protein, and some antioxidants in chickpea and peanut seeds
}

\author{
Vesna Dragičević ${ }^{*}$, Suzana Kratovalieva², Zoran Dumanović ${ }^{1}$ Zoran Dimov ${ }^{3}$ and Natalija Kravić ${ }^{1}$
}

\begin{abstract}
Background: Chickpea and peanut are two legume species not frequently used in human diets. Chickpea is rich in starch and proteins, while peanut is mainly a source of oils and proteins and they could be successfully used as protein sources in vegetarian diets.

Seeds of 19 chickpea and 13 peanut landraces were colorimetrically analyzed in respect to antioxidant content (i.e., free soluble phenolics, total glutathione, and phytate). Oil and protein contents in grain were also determined.

Results: Free soluble phenolics content varied in range from 520 to 1,050 $\mathrm{mg} \mathrm{kg}^{-1}$ in peanut and from 720 to $1,370 \mathrm{mg} \mathrm{kg}^{-1}$ in chickpea. Total glutathione content ranged from 1,495 to 2,365 mmol kg${ }^{-1}$ in peanut and from 955 to $1,232 \mathrm{mmol} \mathrm{kg}^{-1}$ in chickpea. Relatively low content of phytic phosphorus was found in grain of both species, ranging from 2.5 to $4.5 \mathrm{~g} \mathrm{~kg}^{-1}$ in peanut and from 1.4 to $3.0 \mathrm{~g} \mathrm{~kg}^{-1}$ in chickpea, respectively. Considering the lack of data for phytate variability in Macedonian chickpea and peanut local landraces up to date, the observed high variation in phytic phosphorus content could represent the great basis for further breeding programs for phytate decrease in seeds of those genotypes. This is significant, since phytate is an important antinutrient which affects availability of mineral elements. Regression analysis revealed positive and highly significant interdependence between oil content and total glutathione in chickpea seeds, as well as between oil content and phytic phosphorus in peanut seeds. In chickpea, significant and negative correlation between oil and phytic phosphorus content was also observed.

Conclusions: Results obtained indicated that chickpea genotypes with higher oil content could have increased nutritional value due to higher glutathione and lower phytate content observed. However, lower level of phytate content, along with higher level of soluble phenolics and total glutathione found in peanut seeds with lower oil content, indicated higher digestibility and increased antioxidant activity of those genotypes.
\end{abstract}

Keywords: Antioxidants; Nutritive value; Phenolics; Phytic phosphorus; Total glutathione

\section{Background}

Chickpea is a valued legume in Afro-Asian countries due to its nutritive seed composition high in protein content and of better protein quality compared to other legumes, thus increasingly used as a substitute for animal protein. Except of sulfur-containing amino acids, chickpea is rich in all the essential amino acids, being with a balanced content [1]. It has been shown that in vitro protein digestibility from protein isolates ranged between $95.6 \%$ and $96.1 \%$ [2]. Besides, it is also important to emphasize the high antioxidant activity of protein hydrolysates in chickpea [3]. Chickpea seeds contain less than $7 \%$ of oil, with linoleic and oleic acid as predominant

\footnotetext{
* Correspondence: vdragicevic@mrizp.rs

${ }^{1}$ Maize Research Institute, Slobodana Bajića 1, 11185 Zemun Polje, Serbia Full list of author information is available at the end of the article
}

[4]. According to Chitra et al. [5], chickpea contains relatively low phytic acid content, compared to other legumes. Significant and negative correlation between phytic acid and in vitro digestibility made chickpea seeds necessary in human diet. Relatively high genotypic variability is present in chickpea seed composition, including phytic acid and other antioxidants. Rincón et al. [6] found that Desi biotypes revealed lower fat and phytic acid contents, whereas Kabuli biotypes showed lower total dietary fiber, insoluble dietary fiber, and tannin content. Leading role in protection of chickpea seeds against fungal attack was given to phenolic substances [7], which could also contribute to increased nutritional value of chickpea seeds. Beside of particular nutritive parameter, larger seed with light color are considered as desirable traits for chickpea breeding programs [8]. 
Since peanut flour is rich in oil and proteins, it is widely used in different foods: as a replacement for animal source proteins, in breakfast snack foods and cereals, as an improver of cereal flours, and it can be used to produce textured vegetable proteins or can be used directly in ground meats to provide adequate moisture and fat binding characteristics [9]. As an oilseed crop, peanut is characterized with proteins of high quantity and quality, as well as with high caloric value. It is also high in phytic acid and contains fibers and perhaps other binding agents which reduce mineral bioavailability from the seeds [10]. Chemical properties of grain are under high genotypic and environmental impact, reflected in induced variations in oil content, individual fatty acid contents, and derived oil quality parameters [11]. Dwivedi et al. [12] reported significant and negative correlation between oil and protein contents, as well as significant linear increase in oil content followed by seed mass increase. However, no such relationship was observed for protein content. Similarly to chickpea, phenolics from peanut seeds and particularly peanut skin have high antifungal and antioxidative activity [13-15]. Positive effect of peanut on human health can be confirmed by the studies of Emekli-Alturfan et al. [16], who ascertained that addition of peanut to the diet did not significantly change blood lipids, protrombin time, activated partial thromboplastin time, or fibrinogen levels, both in control and in hyperlipidemic groups. Peanut consumption improved glutathione (GSH) and high-density lipoprotein (HDL-C) levels and decreased thiobarbituric acid reactive substances (TBARS), without increasing other blood lipids in experimental hyperlipidemia.

As previously mentioned, peanut seeds are rich in phytic acid which is a strong chelating agent that can bind mono- and divalent metal ions, inducing poor bioavailability of minerals such as zinc, calcium, magnesium, iron, and phosphorus [10]. On the other hand, Chung and Champagne [17] found that phytic acid formed insoluble complexes with the major peanut allergens, resulting in peanut extract with reduced allergenic potency and suggested that phytic acid may find its use in the development of hypoallergenic peanut-based products.

According to findings reported, some of the antinutrients may play important beneficial roles in human diets by acting as anticancerogens or by promoting health in other ways such as in decreasing the risk of heart disease or diabetes. Thus, plant breeders and molecular biologists should be aware of the possible negative consequences of changing antinutrients in major plant foods [18]. In parallel, polyphenols, as well-known classes of phytochemicals, are considered to be important components in human diet. Several studies on cancer cell lines and animal models of carcinogenesis have shown that a wide range of polyphenols possess anticancerogenous and apoptosis-inducing properties [19]. GSH, as protein antioxidant, has important role in free radical scavenging, prevention from stress [20] and could reduce activity of trypsin inhibitors (e.g., Kunitz trypsin inhibitor) [21].

Caloric value of grain, rich in proteins and phytochemicals, enables chickpea and peanut to be broadly and successfully used in vegetarian diets. Hence, to achieve the lower antinutrient content and adequate level of nutritive factors in grain is of great importance.

Those findings prompted us to evaluate a set of 19 chickpea and 13 peanut local landraces in order to determine the content of the main seed constituents (i.e., oil and proteins), as well as seed antioxidant content (i.e., phytate, free soluble phenolics, and GSH). The aim of this investigation was to select the most promising genotypes as sources for further breeding programs for grain quality increase.

\section{Methods}

Average sample of each landrace was presented with 100 uniform seeds. Samples were milled on Perten 120 Sweden (particle size $<500 \mu \mathrm{m}$ ). Oil content was determined as subtraction after extraction with petroleum ether. For protein determination, samples $(4 \times$ of $0.20 \mathrm{~g})$ were digested with $5 \mathrm{ml}$ of mixture $\mathrm{H}_{2} \mathrm{SO}_{4}+\mathrm{H}_{3} \mathrm{PO}_{4}$ (50:1) with addition of $2.5 \mathrm{ml} \mathrm{H}_{2} \mathrm{O}_{2}$ on $420^{\circ} \mathrm{C}$. After that, micro-Kjeldahl procedure [22] was applied for protein determination. Phytic P $\left(P_{\text {phy }}\right)$ and total GSH content were determined after extraction: four replicates of each sample $(0.25 \mathrm{~g})$ were treated with $10 \mathrm{~mL}$ of $5 \%$ trichloroacetic acid for $1 \mathrm{~h}$ at room temperature in a rotary shaker. The extract was centrifuged on $14,000 \mathrm{rpm}$ for $15 \mathrm{~min}$, and the supernatant was decanted and diluted. Phytic P was determined colorimetrically by the method of Dragičević et al. [23], based on the pink colour of the Wade reagent $\left(\mathrm{FeCl}_{3}+5\right.$-sulfosalycilic acid), formed upon the reaction of ferric ion and sulfosalicylic acid. The absorbance of reaction product was determined at $500 \mathrm{~nm}$. GSH was determined from the same extract as $P_{\text {phy }}$, by adding $0.2 \mathrm{M}$ potassium phosphate buffer $(\mathrm{pH}=$ 8.0) and $10 \mathrm{mM}$ DTNB (5.5' -dithio(2-nitrobenzoic acid)) and measuring the absorbance at $415 \mathrm{~nm}$ [24]. Free soluble phenolics were determined after $1 \mathrm{~h}$ extraction with bi-distilled water by method of Simić et al. [25], based on a slightly modified Prussian blue method where $0.05 \mathrm{M} \mathrm{FeCl}_{3}$ in $0.1 \mathrm{M} \mathrm{HCl}$ and $0.008 \mathrm{M} \mathrm{K}_{3} \mathrm{Fe}(\mathrm{CN})_{6}$ were added to sample solution. After $25 \mathrm{~min}$, the absorbance of the reaction product was determined at $722 \mathrm{~nm}$.

\section{Statistical analysis}

All analyses were performed in four measurements $(n=4)$, and the results were presented as mean \pm standard deviation (SD). The differences among chickpea and peanut local landraces, based on mean values of observed 
parameters, were evaluated using regression analysis and principle component analysis (PCA). Statistical analysis was performed by SPSS 15.0 for Windows Evaluation version.

\section{Results and discussion}

Results presented in Table 1 showed that 1,000 seed weight varied in wide range for both species: from 211.7 to $363.6 \mathrm{~g}$ for chickpea landraces and from 420.5 to $661.4 \mathrm{~g}$ for peanut genotypes. According to Toker and Cagirgan [26], seed weight of chickpea is negatively correlated with yield, thus hindering the breeding for high yielding plants, particularly those with larger seeds. However, weight of peanut seeds is a trait, highly influenced by genotypic effect in compare to other factors, including stress [27].

Variations in oil content were insignificant for chickpea seed, ranging from $4.44 \%$ to $5.16 \%$, while for peanut seeds, those variations were higher (i.e., from $43.5 \%$ to $52.4 \%$ ). Our findings were in line with Zia-Ul-Haq et al. [4], who also reported less than $7 \%$ of oil content in chickpea seeds. Besides the differences in oil content between chickpea and peanut, there were also the differences in protein content: in peanut seed, protein content was higher, varying in wider range (i.e., from $18.4 \%$ to 29.1\%) compared to chickpea seeds, where it varied from $11.3 \%$ to $17.6 \%$. Obtained results indicated that seeds of examined peanut landraces could be considered as high oil and protein food, consisting of about $66.6 \%$ to $74.2 \%$ oil + protein content. Dwivedi et al. [12] ascertained that oil and protein content negatively correlate in peanut seeds, which was confirmed with our results, where high oil genotypes, like P1, P7, P8, P9, and P10 have also the lowest protein content. Compared to genotypic variations, environmental factors have shown to have more pronounced effect on variations in oil content of peanut seeds [11].

Group of biomolecules such as antioxidants could additionally improve the nutritional value of produced seeds. Phytic acid, as important antioxidant, could be also considered as antinutrient. According to the results presented in Table 2, examined chickpea landraces have $P_{\text {phy }}$ in wide range from 2.39 to $4.46 \mathrm{mg} \mathrm{g}^{-1}$, while in peanut seeds, $P_{\text {phy }}$ content ranged from 1.44 to $2.96 \mathrm{mg}$ $\mathrm{g}^{-1}$, being in average by $27 \%$ lower compared to chickpea. Since Duhan et al. [28] also determined that chickpea seeds are rich in phytic acid, they recommended soaking, cooking, autoclaving, or sprouting as methods for successful phytate degradation. However, Chung and Champagne [17] found that phytic acid formed complexes with main allergenic proteins from peanut seeds and even suggested that addition of phytic acid to meals that contain peanut could reduce its allergenic properties. Nevertheless, relatively lower $P_{\text {phy }}$ implied potentially
Table 1 Weight of 1000 seed, oil and protein content in investigated chickpea and peanut local landraces

\begin{tabular}{llll}
\hline $\begin{array}{l}\text { Local } \\
\text { landraces }\end{array}$ & $\begin{array}{l}\mathbf{1 , 0 0 0} \text { seed } \\
\text { weight } \mathbf{( g )}\end{array}$ & Oil (\%) & Protein (\%) \\
\hline Chickpea & & & \\
C1 & $330.1 \pm 29.9^{*}$ & $4.69 \pm 0.43$ & $13.68 \pm 0.32$ \\
C2 & $270.3 \pm 28.7$ & $4.85 \pm 0.49$ & $12.36 \pm 0.46$ \\
C3 & $286.6 \pm 28.0$ & $4.99 \pm 0.43$ & $12.60 \pm 0.23$ \\
C4 & $325.7 \pm 28.2$ & $4.89 \pm 0.46$ & $12.39 \pm 0.12$ \\
C5 & $293.2 \pm 30.2$ & $4.72 \pm 0.46$ & $13.70 \pm 0.39$ \\
C6 & $339.5 \pm 35.9$ & $4.66 \pm 0.66$ & $15.19 \pm 0.30$ \\
C7 & $227.5 \pm 30.7$ & $4.44 \pm 0.74$ & $13.22 \pm 0.33$ \\
C8 & $237.8 \pm 28.8$ & $5.16 \pm 0.48$ & $13.02 \pm 0.36$ \\
C9 & $302.1 \pm 32.1$ & $4.95 \pm 0.43$ & $14.61 \pm 0.29$ \\
C10 & $278.3 \pm 26.5$ & $4.67 \pm 0.43$ & $12.18 \pm 0.82$ \\
C11 & $211.7 \pm 29.1$ & $4.78 \pm 0.64$ & $12.81 \pm 0.44$ \\
C12 & $310.1 \pm 25.8$ & $4.81 \pm 0.53$ & $11.26 \pm 0.15$ \\
C13 & $280.1 \pm 31.4$ & $5.14 \pm 0.76$ & $12.82 \pm 0.26$ \\
C14 & $296.0 \pm 33.8$ & $4.44 \pm 0.82$ & $14.60 \pm 0.31$ \\
C15 & $286.4 \pm 35.5$ & $4.91 \pm 0.56$ & $15.17 \pm 0.38$ \\
C16 & $341.3 \pm 33.9$ & $4.74 \pm 0.45$ & $14.80 \pm 0.29$ \\
C17 & $311.1 \pm 37.2$ & $4.65 \pm 0.70$ & $16.43 \pm 0.23$ \\
C18 & $363.6 \pm 39.6$ & $4.64 \pm 0.50$ & $17.63 \pm 0.12$ \\
C19 & $320.8 \pm 32.6$ & $4.71 \pm 0.46$ & $14.88 \pm 0.31$
\end{tabular}

Peanut

\begin{tabular}{llll} 
P1 & $460.0 \pm 40.6$ & $52.39 \pm 0.40$ & $18.56 \pm 0.14$ \\
P2 & $505.7 \pm 53.2$ & $45.29 \pm 0.29$ & $24.51 \pm 0.20$ \\
P3 & $487.8 \pm 51.0$ & $47.44 \pm 0.30$ & $23.96 \pm 0.35$ \\
P4 & $426.1 \pm 58.0$ & $43.50 \pm 0.31$ & $26.77 \pm 0.13$ \\
P5 & $529.4 \pm 59.3$ & $45.22 \pm 0.51$ & $26.84 \pm 0.15$ \\
P6 & $420.5 \pm 61.8$ & $45.03 \pm 0.41$ & $28.67 \pm 0.17$ \\
P7 & $532.3 \pm 44.0$ & $48.89 \pm 0.51$ & $19.71 \pm 0.08$ \\
P8 & $463.3 \pm 46.6$ & $48.52 \pm 0.48$ & $21.21 \pm 0.15$ \\
P9 & $504.1 \pm 17.9$ & $48.18 \pm 0.44$ & $18.37 \pm 7.19$ \\
P10 & $498.1 \pm 46.2$ & $48.54 \pm 0.43$ & $20.97 \pm 0.04$ \\
P11 & $482.8 \pm 47.8$ & $46.83 \pm 0.43$ & $21.94 \pm 0.14$ \\
P12 & $661.4 \pm 63.3$ & $44.32 \pm 0.35$ & $29.10 \pm 0.17$ \\
P13 & $523.2 \pm 58.9$ & $47.33 \pm 0.42$ & $26.91 \pm 0.14$ \\
\hline
\end{tabular}

*The results are represented as mean $\pm S D$ (standard deviation) in four measurements.

higher quality of peanut seeds. According to results of our investigation, chickpea genotypes with $P_{\text {phy }}<2.5 \mathrm{mg} \mathrm{g}^{-1}$, such as C2, C3, C9, and C10 landraces, could be used for breeding program for further phytate decrease, i.e., increased bioavailability of mineral elements.

GSH is protein, but it is not obligatory that seeds rich in proteins have high content of thiolic groups and GSH. Dragičević et al. [29] underlined the importance of GSH 
Table 2 Phytic $\mathbf{P}$, total glutathione, and phenolics content in seeds of chickpea and peanut local landraces

\begin{tabular}{|c|c|c|c|}
\hline $\begin{array}{l}\text { Local } \\
\text { landraces }\end{array}$ & $P_{\text {phy }}\left(\mathrm{mg} \mathrm{g}^{-1}\right)$ & GSH (nmol g $\left.{ }^{-1}\right)$ & Phenolics $\left(\mu \mathrm{g} \mathrm{g}^{-1}\right)$ \\
\hline \multicolumn{4}{|l|}{ Chickpea } \\
\hline $\mathrm{C} 1$ & $2.57 \pm 0.09^{*}$ & $1,496.8 \pm 21.47$ & $522.7 \pm 12.8$ \\
\hline $\mathrm{C} 2$ & $2.43 \pm 0.08$ & $1,687.3 \pm 8.27$ & $571.2 \pm 25.9$ \\
\hline C3 & $2.45 \pm 0.08$ & $2,197.5 \pm 14.34$ & $670.8 \pm 3.2$ \\
\hline $\mathrm{C} 4$ & $2.77 \pm 0.04$ & $1,652.1 \pm 13.21$ & $670.6 \pm 16.8$ \\
\hline C5 & $2.86 \pm 0.02$ & $1,614.2 \pm 757.64$ & $678.5 \pm 26.9$ \\
\hline C6 & $3.85 \pm 0.10$ & $2,008.6 \pm 8.25$ & $686.7 \pm 7.4$ \\
\hline C7 & $4.04 \pm 0.08$ & $1,820.2 \pm 10.61$ & $648.5 \pm 7.4$ \\
\hline $\mathrm{C} 8$ & $2.72 \pm 0.07$ & $2,354.8 \pm 54.99$ & $962.6 \pm 34.8$ \\
\hline C9 & $2.39 \pm 0.03$ & $2,364.3 \pm 12.60$ & $1,026.6 \pm 42.0$ \\
\hline $\mathrm{C} 10$ & $2.45 \pm 0.02$ & $2,302.2 \pm 22.79$ & $1,075.1 \pm 25.6$ \\
\hline $\mathrm{C} 11$ & $3.48 \pm 0.05$ & $2,035.3 \pm 4.87$ & $951.0 \pm 14.1$ \\
\hline $\mathrm{C} 12$ & $3.02 \pm 0.12$ & $1,936.2 \pm 18.18$ & $851.0 \pm 10.2$ \\
\hline $\mathrm{C} 13$ & $4.12 \pm 0.10$ & $2,099.9 \pm 14.58$ & $789.2 \pm 15.7$ \\
\hline $\mathrm{C} 14$ & $4.46 \pm 0.05$ & $1,976.5 \pm 762.23$ & $932.0 \pm 27.7$ \\
\hline $\mathrm{C} 15$ & $3.68 \pm 0.05$ & $2,314.0 \pm 7.69$ & $1,005.8 \pm 52.3$ \\
\hline $\mathrm{C} 16$ & $3.01 \pm 0.05$ & $2,066.6 \pm 20.62$ & $1,051.1 \pm 28.7$ \\
\hline $\mathrm{C} 17$ & $4.16 \pm 0.04$ & $2,210.5 \pm 15.15$ & $909.6 \pm 30.5$ \\
\hline $\mathrm{C} 18$ & $3.39 \pm 0.09$ & $1,953.9 \pm 6.97$ & $984.4 \pm 39.8$ \\
\hline C19 & $3.08 \pm 0.02$ & $1,891.4 \pm 11.68$ & $992.3 \pm 26.4$ \\
\hline \multicolumn{4}{|l|}{ Peanut } \\
\hline P1 & $2.75 \pm 0.11$ & $996.5 \pm 4.58$ & $801.1 \pm 16.8$ \\
\hline P2 & $1.47 \pm 0.11$ & $1,002.0 \pm 19.88$ & $812.7 \pm 553.8$ \\
\hline P3 & $1.44 \pm 0.20$ & $1,034.4 \pm 8.43$ & $727.3 \pm 26.0$ \\
\hline P4 & $1.62 \pm 0.23$ & $1,078.4 \pm 5.99$ & $993.2 \pm 15.7$ \\
\hline P5 & $2.45 \pm 0.14$ & $968.3 \pm 8.16$ & $916.2 \pm 14.8$ \\
\hline P6 & $2.68 \pm 0.11$ & $988.6 \pm 3.72$ & $751.2 \pm 28.6$ \\
\hline P7 & $2.32 \pm 0.15$ & $907.5 \pm 5.82$ & $1,036.1 \pm 26.8$ \\
\hline P8 & $2.95 \pm 0.10$ & $1,042.8 \pm 5.75$ & $1,369.6 \pm 6.2$ \\
\hline P9 & $2.81 \pm 0.19$ & $956.5 \pm 5.91$ & $1,286.9 \pm 27.1$ \\
\hline P10 & $2.68 \pm 0.09$ & $1,008.7 \pm 3.31$ & $1,020.8 \pm 41.5$ \\
\hline P11 & $2.73 \pm 0.13$ & $1,016.4 \pm 8.10$ & $983.9 \pm 17.9$ \\
\hline P12 & $1.75 \pm 0.13$ & $1,006.5 \pm 2.94$ & $1,214.2 \pm 7.7$ \\
\hline P13 & $2.96 \pm 0.10$ & $1,232.5 \pm 4.12$ & $941.4 \pm 20.2$ \\
\hline
\end{tabular}

*The results are represented as mean \pm SD (standard deviation) in four measurements. $P_{\text {phy, }}$ phytic $\mathrm{P} ; \mathrm{GSH}$, total glutathione.

and other thiolic proteins in soybean grain. In this study, GSH from peanut seeds ranged from 727.3 to $1,369.6$ nmol g${ }^{-1}$ (Table 2), while in chickpea seeds, it was in range from $1,496.8$ to $2,364.3 \mathrm{nmol} \mathrm{g}^{-1}$, contributing to higher antioxidant potential of chickpea proteins. Obtained results could be partly supported by the finding of Li et al. [3], who ascertained high antioxidant activity of chickpea protein hydrolysates. Also, relatively high GSH level in examined chickpea landraces (particularly in $\mathrm{C} 8, \mathrm{C} 9, \mathrm{C} 10$, and $\mathrm{C} 15$ ) could be considered as a good source of thiolic amino acids, contrary to Jukanti et al. [1], who established poor sourcing of chickpea grains with thiolics.

Soluble phenolics content varied in high range in seeds of both species, with slightly higher values observed in peanut landraces. In chickpea seeds, phenolics varied in range from 522.7 to $1,075.1 \mu \mathrm{g} \mathrm{g}^{-1}$ and in peanut seeds in range from 727.3 to $1,369.6 \mu \mathrm{g} \mathrm{g}^{-1}$. Chérif et al. [7] underlined the importance of phenolics as antifungal factor for chickpea, as well as Yu et al. [14] and Nepote et al. [15] for peanut. The same authors found that peanut skin rich in phenolics content also have high antioxidative activity.

Interactions between main seed constituents, such as oil, proteins, and antioxidants in chickpea seeds, revealed in significant and negative correlation between $P_{\text {phy }}$ and oil $\left(R^{2}=0.159\right.$; Figure 1$)$, as well as in significant and positive correlation between $P_{\text {phy }}$ and proteins $\left(R^{2}=0.165\right.$; Figure 2). Chitra et al. [5] also observed positive correlation between phytate and proteins, but with lower significance compared to other legume seed. This could mean that irrespectively to relatively low oil and protein content in chickpea seed (Table 1), its nutritional quality could be increased by slight oil increase in parallel with phytate decrease. It is also important to underline that this trend was supported by significant and positive interdependence between oil and GSH content. Oppositely, in peanut seeds, highly positive interdependence was found between phytate and oil $\left(R^{2}=\right.$ 0.273; Figure 1), as well as between proteins and GSH $\left(R^{2}=0.149\right.$; Figure 2). In addition, negative interdependence was observed between phytate and protein content $\left(R^{2}=0.145\right)$. This could indicate that in genotypes with slightly reduced oil and increased protein content, nutritive value of seeds could be higher, due to lower phytate and increased GSH content. This was supported by the findings of Dwivedi et al. [12], who also observed negative correlation between oil and protein content in peanut seeds.

Projection of variables in PCA revealed that in chickpea seeds, GSH and phenolics contributed to PCA1, which explained $39.40 \%$ of the total variability (Table 3 ). The second axis (PCA2), which explained $34.60 \%$ of the variation, was defined only with oil content. This means that traits, such as GSH and phenolics, vary simultaneously. In peanut seeds, oil and proteins contributed to PCA1, which explained $46.60 \%$ of the total variability while $P_{\text {phy }}$ and GSH contributed to PCA2, which explained $23.10 \%$ of the variation. According to the results presented, oil and proteins in peanut seeds vary simultaneously, but in opposite directions. Independent to 

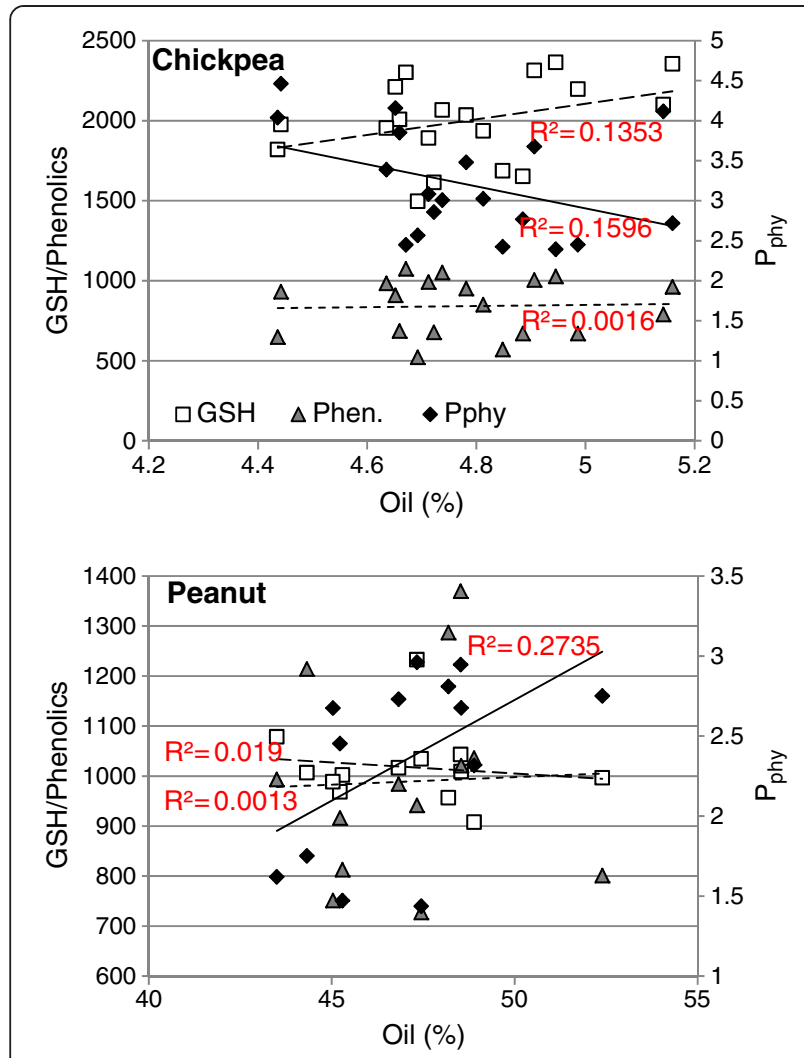

Figure 1 Regression between oil content, phytic P, glutathione, and phenolics in seeds of chickpea and peanut landraces.

main constituents of peanut seed, antioxidants such as phytate and GSH vary simultaneously with higher significance of GSH. This could be important in further breeding programs considering investigated genotypes, since increase in GSH implies $P_{\text {phy }}$ increase to some extent.

\section{Experimental}

\section{Plant material}

Nineteen chickpea and 13 peanut local landraces from Macedonian gene bank (harvested in 2011) were the objectives of the present study.

\section{Conclusions}

Based on the results obtained, it could be concluded that investigated chickpea and peanut genotypes could be considered as highly valuable foods, particularly in vegetarian diets. This could underline the necessity for further breeding, especially if increase in the level of antioxidants is taken into account.

Chickpea landraces, with relatively low oil and protein content could be additionally improved by breeding with slight oil increase, which is related to phytate decrease. It is important to observe that protein composition could be enhanced by GSH increase, along with increase of phenolics, which could reflect in increased antioxidative
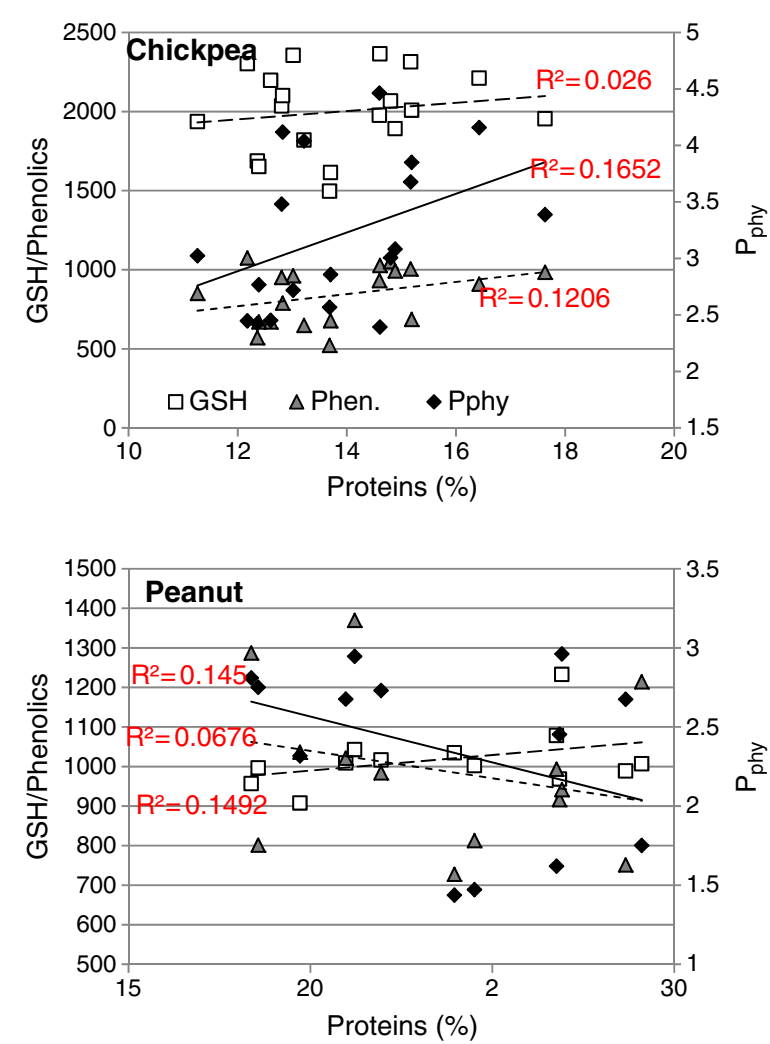

Figure 2 Regression between protein content, phytic $\mathrm{P}$, glutathione, and phenolics in seeds of chickpea and peanut landraces.

capacity. Obtained results indicate that $\mathrm{C} 8, \mathrm{CP} 9, \mathrm{C} 10$, and C15 local landraces could be used as potential source of increased thiolic content in further breeding programs.

Guidelines for further peanut breeding could be associated with oil and/or protein content increase. Parallel increase in proteins and GSH is connected with phytate reduction, which could have positive impact on the availability of mineral elements. However, if positive impact of

Table 3 Principal component analysis for seed chemical composition of chickpea and peanut local landraces

\begin{tabular}{|c|c|c|c|c|}
\hline \multirow[b]{2}{*}{ Variable } & \multicolumn{2}{|c|}{ Chickpea } & \multicolumn{2}{|l|}{ Peanut } \\
\hline & PCA1* & PCA2 & PCA1 & PCA2 \\
\hline Oil & 0.097 & 0.647 & 0.579 & -0.024 \\
\hline Proteins & -0.485 & -0.336 & -0.600 & 0.220 \\
\hline$P_{\text {phy }}{ }^{* *}$ & -0.356 & -0.450 & 0.443 & 0.522 \\
\hline GSH & -0.522 & 0.449 & -0.213 & 0.763 \\
\hline Phenolics & -0.597 & 0.254 & 0.250 & 0.313 \\
\hline Explained variance & 1.971 & 1.732 & 2.329 & 1.157 \\
\hline Proportion of total variance (\%) & 39.40 & 34.60 & 46.60 & 23.10 \\
\hline
\end{tabular}

*Synthetic variables: PCA1, principal component axis 1 and PCA2, principal component axis 2 . PCA, principal component analysis; ${ }^{* *} P_{\text {phy, }}$ phytic $\mathrm{P}$; $\mathrm{GSH}$, glutathione. 
phytate on lowering of allergenic properties of peanut seeds was taken into consideration, it's increase, along with GSH and phenolic increase, could additionally raise antioxidative properties of peanut seeds.

\section{Competing interests}

The authors declare that they have no competing interests.

\section{Authors' contributions}

VD and SK designed the research. SK and ZD (Dimov) provided seeds of chosen chickpea and peanut local landraces for the analyses. VD performed chemical analyses. ZD (Dumanović) analyzed the data. VD and NK wrote the paper. All authors read and approved the final manuscript.

\section{Acknowledgements}

This study was supported by Project TR31068 'Improving the quality of maize and soybean by conventional and molecular breeding' from the Ministry of Education, Science and Technological Development, Republic of Serbia and by COST Action FA 0905 'Mineral Improved Crop Production for Healthy Food and Feed'.

\section{Author details}

'Maize Research Institute, Slobodana Bajića 1, 11185 Zemun Polje, Serbia. ${ }^{2}$ State Phytosanitary Laboratory, Ministry of Agriculture, Forestry and Water Economy, Aminta Treti 2, 1000 Skopje, Republic of Macedonia. ${ }^{3}$ Faculty of Agricultural Sciences and Food, University Ss Cyril and Methodius, Aleksandar Makedonski bb, 1000 Skopje, Republic of Macedonia.

Received: 22 September 2014 Accepted: 6 January 2015

Published online: 01 February 2015

\section{References}

1. Jukanti AK, Gaur PM, Gowda CL, Chibbar RN (2012) Nutritional quality and health benefits of chickpea (Cicer arietinum L.): a review. Br J Nutr 108(Suppl 1):S11-S26

2. Sánchez-Vioque R, Clemente A, Vioque J, Bautista J, Millán F (1999) Protein isolates from chickpea (Cicer arietinum L.): chemical composition, functional properties and protein characterization. Food Chem 64(2):237-243

3. Li Y, Jiang B, Zhang T, Mu W, Liu J (2008) Antioxidant and free radicalscavenging activities of chickpea protein hydrolysate (CPH). Food Chem 106(2):444-450

4. Zia-Ul-Haq M, Ahmad M, Iqbal S, Ahmad S, Ali H (2007) Characterization and compositional studies of oil from seeds of desi chickpea (Cicer arietinum L.) cultivars grown in Pakistan. J Am Oil Chem Soc 84(12):1143-1148

5. Chitra U, Vimala V, Singh U, Geervani P (1995) Variability in phytic acid content and protein digestibility of seed legumes. Plant Food Human Nutr 47(2):163-172

6. Rincón F, Martínez B, Ibáñez MV (1998) Proximate composition and antinutritive substances in chickpea (Cicer arietinum L.) as affected by the biotype factor. J Sci Food Agric 78(3):382-388

7. Chérif M, Arfaoui A, Rhaiem A (2007) Phenolic compounds and their role in bio-control and resistance of chickpea to fungal pathogenic attacks. Tunisian J Plant Protect 2:7-21

8. Graham J, Matassa V, Panozzo J, Starick N (2001) Genotype and environment interaction for wholeseed colour in chickpea. In: Proceedings of the $4^{\text {th }}$ European Conference on Seed Legumes, 8-12 July 2001. Cracow, Poland, pp 372-373

9. Yu J, Ahmedna M, Goktepe I (2007) Peanut protein concentrate: production and functional properties as affected by processing. Food Chem 103(1):121-129

10. Erdman JW (1979) Oilseed phytates: nutritional implications. J Am Oil Chem Soc 56(8):736-741

11. Dwivedi SL, Nigam SN, Jambunathan R, Sahrawat KL, Nagabhushanam GVS, Raghunath K (1993) Effect of genotypes and environments on oil content and oil quality parameters and their correlation in peanut (Arachis hypogaea L.). Peanut Sci 20(2):84-89

12. Dwivedi SL, Jambunathan R, Nigam SN, Raghunath K, Ravi Shankar K, Nagabhushanam GVS (1990) Relationship of seed mass to oil and protein contents in peanut (Arachis hypogaea L.). Peanut Sci 17(2):48-52
13. Sanders TH (1977) Changes in tannin-like compounds of peanut fruit parts during maturation. Peanut Sci 4(2):51-53

14. Yu J, Ahmedna M, Goktepe I (2005) Effects of processing methods and extraction solvents on concentration and antioxidant activity of peanut skin phenolics. Food Chem 90(1-2):199-206

15. Nepote V, Grosso NR, Guzmán CA (2005) Optimization of extraction of phenolic antioxidants from peanut skins. J Sci Food Agric 85(1):33-38

16. Emekli-Alturfan E, Kasikci E, Yarat A (2007) Peanuts improve blood glutathione, $\mathrm{HDL}$-cholesterol level and change tissue factor activity in rats fed a high-cholesterol diet. Eur J Nutr 46(8):476-482

17. Chung SY, Champagne E (2007) Effects of phytic acid on peanut allergens and allergenic properties of extracts. J Agric Food Chem 55(22):9054-9058

18. Graham RD, Welch RM, Bouis HE (2001) Addressing micronutrient malnutrition through enhancing the nutritional quality of staple foods: principles, perspectives and knowledge gaps. Adv Agron 70:77-142

19. Khan HY, Zubair H, Ullah MF, Ahmad A, Hadi SM (2012) A prooxidant mechanism for the anticancer and chemopreventive properties of plant polyphenols. Curr Drug Targets 13:1738-1749

20. Santos CVD, Rey P (2006) Plant thioredoxins are key actors in the oxidative stress response. Trends Plant Sci 11:329-334

21. Kobrehel KS, Yee BC, D'Buchanans B (1991) Role of the NADP/thioredoxin system in the reduction of a-amylase and trypsin inhibitor proteins. JBC 266:16135-16140

22. AOAC. (1984) Official Methods of Analysis of the Association of Official Analytical Chemists. S. Williams (Ed.). Association of Official Analytical Chemists, Arlington, Virginia, USA

23. Dragičević V, Sredojević S, Perić V, Nišavić A, Srebrić M (2011) Validation study of a rapid colorimetric method for the determination of phytic acid and inorganic phosphorus from grains. Acta Period Technol 42:11-21

24. Sari Gorla M, Ferrario S, Rossini L, Frova C, Villa M (1993) Developmental expression of glutathione-S-transferase in maize and its possible connection with herbicide tolerance. Euphytica 67:221-230

25. Simić A, Sredojević S, Todorović M, Đukanović L, Radenović Č (2004) Studies on the relationship between content of total phenolics in exudates and germination ability of maize seed during accelerated aging. Seed Sci Technol 32:213-218

26. Toker C, Cagirgan Ml (2004) The use of phenotypic correlations and factor analysis in determining characters for seed yield selection in chickpea (Cicer arietinum L.). Hereditas 140(3):226-228

27. Pandey RK, Herrera WAT, Pendleton JW (1984) Drought response of grain legumes under irrigation gradient: I. Yield and yield components. Agron J 76(4):549-553

28. Duhan A, Chauhan BM, Punia D, Kapoor AC (1989) Phytic acid content of chickpea (Cicer arietinum) and black gram (Vigna mungo): varietal differences and effect of domestic processing and cooking methods. J Sci Food Agric 49(4):449-455

29. Dragičević V, Perić V, Srebrić M, Žilić S, Mladenović-Drinić S (2010) Some nutritional and anti-nutritional factors of ZP soya bean varieties. J Agric Sci 55(2):141-146

\section{Submit your manuscript to a SpringerOpen ${ }^{\odot}$ journal and benefit from:}

- Convenient online submission

- Rigorous peer review

- Immediate publication on acceptance

- Open access: articles freely available online

High visibility within the field

- Retaining the copyright to your article

Submit your next manuscript at $>$ springeropen.com 